Matematikai Közlemények

VI. kötet, 2018

doi:10.20312/dim.2018.07

\title{
Középkori számolási eljárásokról
}

\author{
Porubszky István \\ Cseh Tudományos Akadémia Informatikai Kutatóintézete, Prága \\ sporubsky@hotmail.com
}

\begin{abstract}
ÖSSZEFOGLALÓ. A dolgozatban bemutatunk néhány módszert arra, ahogyan a négy alapmüveletet használták középkorban, és dióhéjban körvonalazzuk a történelmi hátterüket.
\end{abstract}

\begin{abstract}
In the paper, several medieval algorithms for four basic arithmetic operations are presented together with a short outline of their historical background.
\end{abstract}

\section{Bevezetés}

A különféle nézetek szerint a 14 - 17. század közötti időszakaszban ért véget a középkor. Több nagy jelentőségü esemény is az európai tudományok fejlődését segítette, és Európa a tudományos és kulturális vezető szerepet átvette Kína és az arab világ helyett. A tudományos gondolkozásban új, fontos szerepet kaptak a kísérletek, és új technológiai ötletek vezettek a káoszból az új rend felé.

A tudomány és a matematika még a 14. században is részben a hittudomány szolgálatában állt. A számolást gyakorlati céloktól vezérelve tanították, például egyházi ünnepnapok kiszámításához. Szent Ágoston (354-430) hangsúlyozta a számok ismeretének fontosságát és számokról A keresztény tanitásról címü müvében írja [2, XXXIX,56]: ... a számtant sem az emberek hozták létre, hanem csak rájöttek és kipuhatolták szabályait ... hogy háromszor három ne legyen kilenc, ... hogy a hármas számhoz viszonyítva ne legyen háromszoros, a hatoshoz mérve egyszer és félszer akkora, hogy valamely számnak a kétszerese legyen, mivel a páratlan számoknak fele nincsen ... változatlan szabályok vannak, melyek semmikép sem emberi alkotások, hanem csupán a tehetségesek éleselméjüségének leleményei. A hagyományos vélekedés szerint Ágoston a matematikát mindennél jobban gyülölte, és a matematika nála nem tudomány, mert több helyen megtalálható ez a fordítás (A Genezisről szó szerinti értelemben, 2, XVII, 37): Jó keresztények óvatosak legyenek a matematikusokkal és minden más tanítóval, kik üres dolgokat hirdetnek. A veszély már régóta valóságos, hogy a matematikusok szövetséget kötöttek az ördöggel az ember lelke elhomályosítására, és az ember pokolhoz láncolásában. Nagyon valószínütlennek tünik, hogy Sz. Ágoston, mint a kereszténység és különösen a nyugati gondolkodás egyik központi személyisége, és az első középkori és utolsó ókori gondolkodónak tekintendő, ilyen negatív kapcsolatban állna a matematikával. Nagyon valószínű, hogy a helytelen hivatkozás rossz fordításból ered. Az ágostoni időben a mathematici állat a numerológusokat vagy az asztrológusokat jelentették.

Persze, korábban és később is találhatunk kiemelkedő tudósokat, akik nem szerették a matematikát. Al-Gazáli (1058-1111) arab nyelvü perzsiai muszlim teológus és filozófus, az 
egész iszlám világ egyik legnagyobb gondolkodója szerint a számok manipulálása az ördög munkája.

Aurillaci Gerberttet (940-1003), a későbbi II. Szilveszter pápát (999 - 1003) boszorkánysággal gyanúsították matematikai és rendkívüli számolási képessége miatt. Öneki, aki a Szent István királyunknak koronát küldött, pontosabban a mai korona felső részét és megalapította Magyarország első (Esztergomi) érsekségét, tulajdonítjuk az arab számjegyeknek bevezetése Európában. Azok használatát Spanyolországban, az arab műveltség európai központjában Cordobában tanulta meg. Mint első nyugat európai tudós honosította meg a nyugat Európában a mórok által közvetített szanszkrit számjegyekkel való számolási eljárásokat, melyeket másfél évszázaddal korábban Al-Khvarizmi fejlesztett ki. Olyan számításokat tudott fejben elvégezni, amelyek nagyon nehezek voltak azok számára, akik csak római számokat használtak. Ez pedig nincsen az ördöggel való cimboraság nélkül.

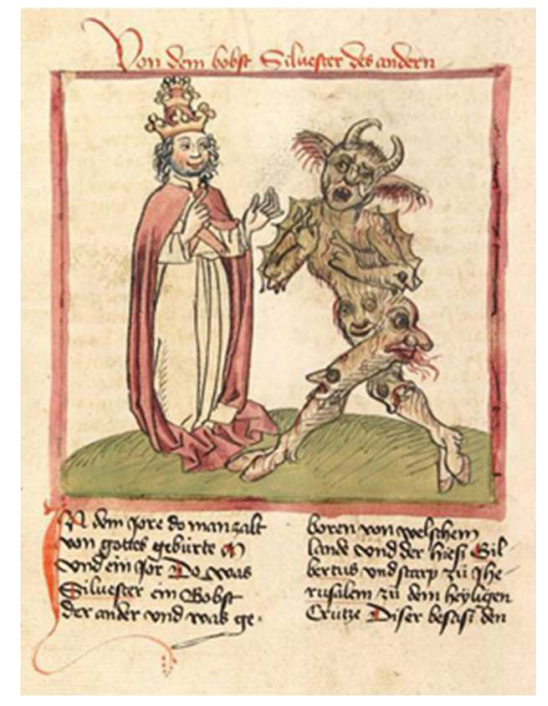

1. ábra. II. Szilveszter és az ördög Chronicon pontificum et imperatorum (1277) szerint

A középkori idő végének egy lényeges vonásának a matematika kiemelkedése bizonyult. Thomas Bradwardine (1290 - 1349), középkori angol matematikus, csillagász, az Oxfordi Egyetem magisztere, teológiai doktor és rövid ideig canterbury érsek, már abban az irányba érvel, hogy a számok az alapja az egész természetfilozófiának. A matematika a kinyilatkoztatója minden valódi igazságnak.

Nem mind arany, ami fénylik. Jacques Le Goff (1924 - 2014) a híres francia történész, a középkorra orientált szakértő, egyik könyvében [1] így jellemezte a középkori népi számítási képességet: A középkor nem számol a 12. századig, vagy legalábbis nem szereti a számokat. Amikor a középkori emberek számokat használnak, azok szimbólumok számukra: 3, 7, 12 és többszöröseik, vagy nagy szám, ezer vagy millió. ... A középkori falusiak nem írnak. A forrásokban csak közvetve jelennek meg, abban amit a papság mond róluk. De a középkori Európa nyolcvan százaléka falusi.

\section{Matematika a középkori egyetemeken}

Az az egyetemi világ és egyetemi rendszer, amit ma ismerünk, középkori alapokon nőtt fel. Az első európai egyetemek katedrálisok mellett jöttek létre. A középkori egyetemek viszont egyedülálló intézmények voltak, teljesen másképpen szerveződtek, mint a korábbiak. Bár egyházi alapításúak voltak, mégis teljes önállósággal rendelkező szervezeteknek 
számítottak, és a pápát kivéve minden egyházi és világi hatalomtól függetlenek voltak. II. Szilveszter volt az atyja az úgynevezett quadrivium négy tudományágának bevezetésével, ami az aritmetikából, a geometriából, a zenéből és az asztrológiából (csillagászatból) állt össze. Ö bővítette ki addigi trivium (a grammatika, a dialektika és a retorika) tárgyakat. Gerbert ezeket a tudományokat még az arabok szomszédságában müködő ibériai kolostorokban sajátította el. Azt megelőzően Gerbert a trivium alapján tanított.

A legalsó szintű egyetemi végzettség, a baccalaureus ("babérkoszorús") cím volt - ezzel a fokozattal taníthattak az alsóbb iskolákban. Két-három évi további tanulás után a magister ("mester") fokozatot lehettet elérni, amely jogot adott előadások tartására a szabad müvészetek karán.

Az alapítást követő években a prágai Károly Egyetem hallgatóinak a baccalaureus cím eléréséhez Joannis de Sacro-Bosco Algorismus címü (más néven De arti numerandi) könyvéről szóló előadásokat kellett hallgatniuk. Ez a könyv jelentősen befolyásolta Európában az arab számok használatát a 13. század végén. A könyv versekbe volt írva az aritmetikai szabályok egyszerúbb memorizálása érdekében (természetesen latinul). A 11 fejezetet mindegyike egy-egy aritmetikai müvelettel foglalkozott: numeráció (az indiai számok olvasása és írása), összeadás, kivonás, felezés, kettőzés (duplázás), szorzás, osztás, a számtani sorozat összegzési képlete, négyzet- és köbgyökvonás, stb., abban az időben ezek mindegyike különálló müvelet jelentett.

Előadásokon a hallgató megtanulta azt is, hogy kell az abakuszon kavics segítségével számolni. Hallgatónak 3 heti előadásért fél prágai garast kellett fizetni.

Különböző módszerek maradtak fenn az ókori Egyiptomból, Babilonból, Görögországból, az Indus-völgyből, és Kínából. Kétszerezést először az egyiptomiak használták a szorzáshoz. Az egyiptomi matematika számírása és a számolás additív volt. Számírásuk 10-es alapú, és a 10 hatványaira különböző jeleket használtak. A szorzást kezdetben kettőzésre vezették vissza (később tízszereztek is). Az egyiptomiak igyekeztek mindent összeadásra vezetni vissza, és csak három aritmetikai műveleteket ismertek:

- összeadás,

- kivonás,

- kettőzés.

A kettőzés nem a kettővel való szorzást jelenti a mai felfogásban, mert a kettővel való szorzás elvégezhető az egyszeregy ismerete nélkül, hiszen elegendő összeadni a számot önmagával. Az egyiptomi módszer a Jahmesz által írt Rhind-papirusz szerint sorozatos kettőzésen és összeadáson alapul. Például a 13 és 21 egyiptomi összeszorzása kettőzésekkel (mai jelölésekkel, bal tábla):

\begin{tabular}{lll}
$\checkmark$ & 1 & 21 \\
& 2 & 42 \\
$\checkmark$ & 4 & 84 \\
$\checkmark$ & 8 & 168 \\
\hline & 13 & 273
\end{tabular}

\begin{tabular}{lll}
$\checkmark$ & 13 & 21 \\
& 6 & 42 \\
$\checkmark$ & 3 & 84 \\
$\checkmark$ & 1 & 168 \\
\hline & & 273
\end{tabular}

Az egyiptomi számolómester addig folytatta a kétszerezést, ameddig elérte, hogy az első tényező, jelen esetben a 13, összetehető a bal oldali oszlopban álló kettes hatványokból, ezeket a kétszerezés közben megjelölte, és a végén az alkalmas szorzatokat a jobb oldalon összeadta.

Ahogy itt leírtuk, ezt az óegyiptomi szorzási módot még a középkorban is tanították Európa-szerte. Az egyiptomi múveletekhez hozzátartozik még a felezés. Az egyiptomi szorzás a középkorban a „kétszerezés és felezés” módszerévé fejlődött ki. Megjegyezzük, hogy bár az utóbbi két művelet meglepő számunkra, a középkorban szerepelnek az aritmetikai 
müveletek listájában. Például, 1400 körül a cseh matematikus, csillagász és orvos Prachatici Christian (Křišt’an z Prachatic) írta az Algorismus prosaycus elnevezésủ tankönyvet a prágai Károly Egyetem hallgatói számára, amelyben így írt: megpróbáltam röviden összeállítani a számítási müvészet alapjait. A munka megkülönböztet kilenc aritmetikai műveletet a fent említett de Sacro-Bosco könyvben leírtak szerint.

A fenti felezést az ún. orosz parasztok szorzás használta, amelynél csak ismételt kettőzésre és felezésre van szükség (jobb tábla), és ezért elönyös volt az tanulatlan orosz muzsikok számára. Egymás mellé írjuk a két összeszorzandó számot. Az egyiket (leginkább a nagyobbikat) duplázzuk, de a másikat felezzük. Ha kapunk maradékot, azt elhagyjuk. Ezt addig végezzük, amíg a felezéssel el nem jutunk 1-ig. Az így duplázással kapott olyan számokat, amelyikek a felezéses oszlopban páros számot tartalmaznak, kihagyjuk. A megmaradt számokat összeadjuk, és az összeadás eredménye a adott két szám szorzata.

\section{Ujjak - a legrégebbi digitális számítógép}

A középkori ember toll és papír nélkül végzett minden számítást (elszigetelt esetekben részeredményeket jegyzett le), de nem segédeszközök nélkül. A legfontosabb, elengedhetetlenek és mindig elérhetők voltak a saját kezei és a saját ujjai. A kéz ujjai mint egy több golyós számláló eszköz müködtek (a golyók mint ujjízületek szerepeltek, a kéz tenyér, és ha szükség volt rá, erre a célra használta az ujjbegyeket, tenyérrészeket, stb.). A számoló gyakran mnemotechnikai verseket használt, amelyeket a számításnál hangosan mondott fel magának fejböl, és amelyikek a numerikus értékeket kódolták.

Erről a tényről, hogy az ujjakkal való számolás valamikor fontos szerepet játszott az életben, tanúskodik a nyelvünk. A számjegyeket angolul digits és a franciául doigts szavak jelölik. Mindkét kifejezés a latin digitus (ujj) szóból származik.

A számok ábrázolása ujjak segítségével (jelenleg is használt rendszer) a benedekrendi szerzetestől, tiszteletre méltó Szent Bédatól (Venerabilis) (672/673 - 735) származik. A rendszert leírta $A z$ idő számításáról (De temporum ratione) címü munkájába. Mégpedig annak az első fejezetében, az Tractatus de computo, vel per loquela gesztusok digitorum-ban. Ez az első írásban fennmaradt ábrázolás az ujjakon való számolásról. A rendszer lehetővé teszi a két kézzel való számolást 9999-ig, de nehézkes a 100 feletti értékekkel. Béda rendszerét az egész középkorban használták. Valószínüleg Béda nélkül az ujjakon számolás, mint egy európai középkori kulturális-történelmi kategória, feledésbe merülne, mivel minden későbbi írás visszatér a Béda fejtegetéséhez. Az ujjakkal való számolásra figyelmet szentelt Fibonacci is a Liber Abbaci müvében. Az első fejezetének végén egy részletes leírást ad az ujjakkal történő számolásról. Az olasz ferences rendi szerzetes, egyetemi tanár, és matematikus Luca Pacioli (1445? - 1514), Leonardo da Vinci matematikatanára, részben módosított Béda rendszerét a nagy enciklopédikus könyvében, az egyik leghíresebb müben, és az egyik első nyomtatott könyvben: Summa de arithmetica, geometrica, propotioni et proporcionalita, (Az aritmetika, a geometria, az arányok, és az aránylatok összefoglaló tárgyalása), amely 1494-ben jelent meg Velencében, ráadásul nem latin, hanem olasz nyelven. A Béda-féle rendszerben, az ujjak mozgatása és pozícionálása jelzi a különféle számokat, különbözőképpen behajlított ujjak jelölték az egyeseket, tízeseket, stb.

Európában a középkorban gyakorlat volt az ujjakon történő számlálás. Ujjaink nem csak összeadni és kivonni segítenek nekünk, hanem szorzáshoz is használhattuk. Az egyik ilyen rendszert, a regula ignavi-t, néha cigány (egy másik módosítása: pillangó) szorzásnak is nevezik. Az eljárás a következő: mindkét kezünkön annyi ujjat egyenesítünk ki, amennyivel a tényező nagyobb, mint 5. Ekkor az egyenes ujjak összege adja a tízek számát és a fel nem emelt ujjak (a kéz tenyerében rejtett ujjak) szorzata eredményezte az egyeseket. Ennek a módszernek létezik szinte egy „negatív” változata is: Mindkét kezünken annyi ujjat hajlítsunk 
be, amennyivel a tényező nagyobb, mint 5. A behajlított ujjak összege adja a tízesek számát, az emelt ujjak szorzata pedig az egyeseket. Ennek az eljárásnak az az elönye, hogy lecsökkenti az egyszeregy szorzótábla ismereteit a negyedrészre, $5 \times 5$-ösre. Az eljárás bizonyítása nagyon egyszerü: $(5+a)(5+b)=10(a+b)+(5-a)(5-b)$.

\section{Abakusz}

Az abakusz az első számolóeszköz, amelynek ősi formáit majdnem minden ókori kultúrában, és valószínüleg egymástól függetlenül, használták. Megnevezésére sokszor helyi nevét használták: számvetö (magyar), szcsoti (orosz), szuan-pan (kínai), szoroban (japán), stb. Érdekes az orosz szcsoti abakusz verzió. A középkor vége felé a kínai abakusz eljutott Oroszországba és ott az európai hatás alapján módosulva terjedt el, és mostanáig használatban van.

Rómában kőből, bronzból vagy agyagból készített abakuszt használtak, amelyeken kavicsokkal (calculi) számoltak. A számolás latin eredetü neve calculare, amely a számológépek angol eredetủ kalkulátor elnevezésének is az eredete, a kavics azaz calculus szóból származik (innen származik tehát a latin calculus (számolás) szó). Másik formája több, vékony rudat vagy pálcát tartalmaz, amelyek mindegyikén esetleg különböző színú, meghatározott számú és rendủ csúsztatható korong vagy golyó található. Gyakran csak egy hét barázdával ellátott agyagtábla volt, mindegyik barázda a római számok egyikét képviselte. A golyókat ezekben a barázdákban lehettet mozgatni. Ezek segítségével végezte el a kezelő az összeadás és a kivonás műveletét.

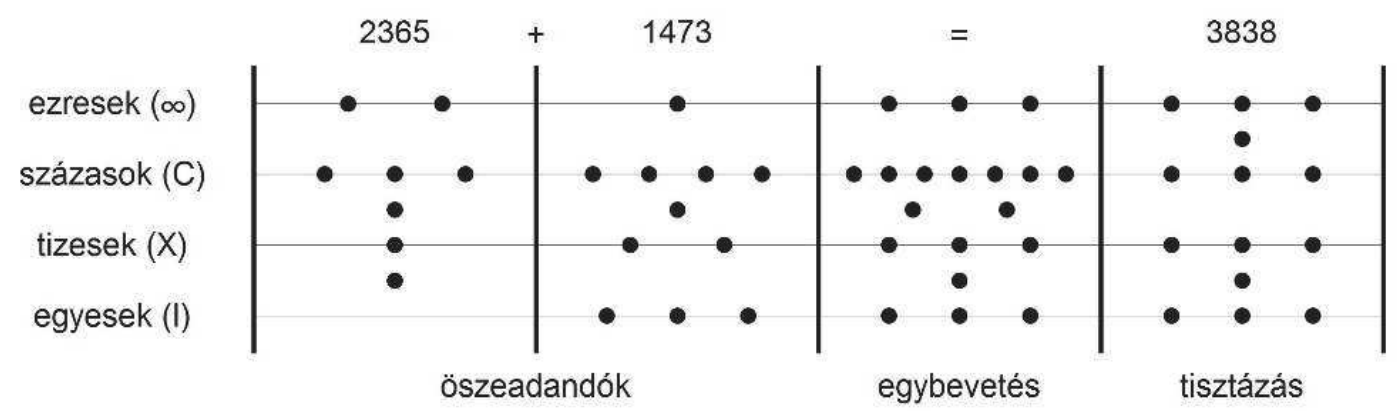

2. ábra. Összeadás abakusszal

Szorzás és osztás elvégzésére csak bonyolult szabályokkal alkalmazható. Például, az elsődleges probléma a szorzásnál, amely a legmagasabb hatványtól kezdődik, abban áll, hogy azt a legmagasabb 10 hatványt meg kell határozni, vagyis az abakusz szempontjából azt a barázdát kitüzni, amelybe szorzat első golyója kerül. Ehhez egy kényelmes szabály van, hogy ez $c=a+b-1$ barázda lesz, ahol $a$ a szorzandó által elfoglalt barázdák száma, $b$ a szorzóval elfoglalt barazdák száma, és $c$ a szorzat barázdáinak száma. Ezt a szabályt már Arkhimédész (kb. i.e. 287 - i. e. 212) is ismerte, és a középkori abakuszisták használták.

Középkori Európában használtak még egy 30 oszlopba osztott sima falapot, általában az első hármat törtszámokkal való számoláshoz, a megmarad oszlopokat a természetes számokkal történő számolására (egységek, tizesek, százasok, stb). Aurillaci Gerbert bevezetett egy érdekes abakusz módosítást: ahelyett hogy a kavicsokat rakta a megfelelő helyre vagy oszlopokba, számolási bélyegeket (apex, apices) használt a keleti arab számjegyekkel (úgynevezet ghubar (,homoktábla” vagy „,portábla”)). Így valójában a tizedes helyiértékes rendszert (nulla nélkül) alkalmazta, és később csak a kolostori iskolákban jelent meg. Egyébként a 15. század végéig az abakuszt a római számjegyekkel használták. 
A 12. század végétől az abakuszt az asztalra rajzolt vonalakból álló táblázat váltotta fel. Ennek az eljárásnak az az előnye, hogy nincs szükség semmilyen eszközre. Elég volt több párhuzamos vonalat megrajzolni és minden vonalhoz egy nagyságrendet (egyesek, tízesek, százasok, stb.) hozzárendelni. A kavicsokat vagy a vonalakra vagy a köztük lévő hézagokban (ahol a fele értékük volt) helyezték el. Ezt még a 16. században is sikeresen használták. A számvető táblák a középkori kereskedők nélkülözhetetlen eszközei volták. Később a számvetők vagy letörölhető táblákon számokkal, vagy abakuszon számoló pénzekkel számoltak. A számoló asztalok vagy táblák mellett használták még ún. számoló-terítőket vagy számoló-szőnyegeket. Ezek tulajdonképpen egy textíliára hímzett vagy rajzolt abakuszt alkotnak, melyet bárhol le lehetett kiteríteni és használni. A régi francia bure, burel szóból, amely "durva gyapjú"-nak felel meg, származik a bureau, Büro, stb.

A római számokat a 14. századig használták, amikor a matematikai és gazdasági számításokban lassan de visszavonhatatlanul kiszorították öket az indiai-arab számok. Fibonacci (1180? - 1250), aki jelentősen segített az arab számok európai felhasználásában, a Floss címü müvében az $x^{3}+2 x^{2}+10 x=20$ egyenletet tárgyalja. Anélkül, hogy jelezné, hogyan találta meg az egyenlet egy közelítő megoldását, váratlanul a hexadecimális rendszerben adja meg azt: $1^{o} 22^{\prime} 7^{\prime \prime} 42^{\prime \prime \prime} 33^{i v} 4^{v} 40^{v i}$. Azt a tényt, hogy az arab számok általános használata lassan terjedt el, mutatja, hogy pl. Kopernikusz kétféle módon írta a számokat. A hatvanas alapú rendszerben írt és fokokba mért szögeket római számokkal jegyezte, ugyanakkor az egész számokban mért hosszúságokat arab számokkal.

\section{Aritmetikai múveleteket}

A középkorban még a négy alapművelet elvégzése sem volt egyszerü feladat. A 15. század végén a nagyobb írásbeli feladatok még inkább előtérbe helyezték a vonalakon történő számolást. A tizedes helyiértékes rendszer elterjedésével az aritmetikai múveleteket kezdték írásban végrehajtani és a használt módszereket fokozatosan tökéletesítettek. Maga számítás balról jobbra haladt, ami azt jelentette, hogy a legmagasabb helyiértékü helyen kezdték. Ez okozta azt, hogy a részleges eredményeket a számítás során gyakran kellett korrigálni, mert az alsóbbrendü jegyek befolyásolták a már kiszámított felsőbb rendủ részeredményeket. Ezek az eljárások általában Indiánból terjedtek el, ahol poros- vagy homoktáblákon végezték el őket, lehetővé téve a részleges eredmények egyszerü törlését és azonnali módosítást. Európában ezeket a eljárásokat papíron kezdték végrehajtani, és emiatt a eredmények törlése nem volt

ennyire egyszerü. Ezért az eredmények törlését a szükségtelen számjegyeknek áthúzás váltotta fel. A számítás eredményét azután a megmaradt számjegyekből állították össze.

\section{1. Összeadás}

A számoló felírta az összeadandókat egymás alá, az eredményt pedig általában föléje írta. Például $3478+5673+9784=1893$. Összeadni a legmagasabb helyiértékü helyen kezdtek:

\begin{tabular}{rrrrr} 
& 8 & 9 & 3 & \\
1 & 7 & 7 & 7 & 5 \\
\hline 3 & 4 & 7 & 8 \\
5 & 6 & 7 & 3 \\
9 & 7 & 8 & 4
\end{tabular}

Ezt az összeadási módszert megtalálhatjuk még a 16. századi tankönyvekben, és időnként később is. 


\subsection{Kivonás}

A kivonást a középkorban többféle módon végezték el. Az első módszer Indiából származik, és hasonló az előbb leírt összeadáshoz. A kisebbítendőt és a kisebbítőt írjuk egymás alá és balról jobbra vonunk ki.

Egy második kivonási módszer ún. tizes kiegészítéssel Európában fejlődött ki. Az 1, 2, .., 9 számjegyeknek a tizes kiegészítése: $9=10-1,8=10-2, \ldots, 1=10-9$. A számoló az első sorba beírta a kisebbítendőt, alatta a második sorba a kivonandót, és a különbséget harmadik sorba alattuk. Maga a számítás itt is jobbról balra történt. Ha a kivonandóban egy kisebb számjegy állt mint a kisebbítendőben, vagy ez a két szám azonos volt, akkor a két számjegy kivonását a jelenlegi kivonási módon végezték. Ha azonban a kisebbítendőbe kisebb számjegy állt, mint az alatta levő kivonandónak a számjegye, akkor a kivonandó számjegyet a tízes kiegészítésével cserélték fel, és ezt a új értéket a kisebbítendő számjegyhez adták hozzá, és ezt a összeget írtak le mind eredményt. Egyúttal a következő kivonandó számjegyhez egyet hozzáadtak.

Például a $67-48$ kivonásnál a kivonás utolsó helyén $7-8$ van, amit ,nem lehetet megtenni”, azért a 8 helyett vették a tízes kiegészítését, amelyiket hozzáadtak a 7-hez, és így kapták meg a különbség utolsó számjegyét: 9. Az eredménynek az első számjegye $6-(4+1)=1$.

Ez a módszer nyilvánvalóan azért igaz mert $a-b=a+(10-b)-10$.

\subsection{Szorzás}

A szorzási algoritmusok fejlődése egy kicsit változatosabb. A használt algoritmusok többsége Indiából származik. Minden szorzási algoritmus feltételezi az egyszeregy ismeretét, azaz a $1 \times 1$-től $9 \times 9$-ig a szorzatok tudását. Mégis ennek a kis egyszeregynek az ismerete túlságosan nagy igényt jelentett a középkori számolók számára, ezért olyan módszereket fejlesztettek ki, amelyben a szorzótáblának csak egy kisebb részét kellett fejben tartaniuk. Egyik ilyen módszert, ahol csak $5 \times 5$-ig kellett az egyszeregyet megtanulni, az Ujjak $-a$ legrégebbi digitális számológép fejezetben már láttunk.

Az egyik középkori eljárás, amelyet a többszámjegyü számok szorzásra használták, és amelyet galea, vagyis hajó néven neveztek, szintén indiai eredetü. Megint a legmagasabb számjegytől kezdték, és fokozatosan, szükség szerint használták a részeredmények törlését. Amikor az európaiak ezeket az eljárásokat papíron kezdték végrehajtani, a törlést a részleges eredmények áthúzásával és fölé írással helyettesítették. Az így létrejövő számításnak a lejegyzése egy vázlatos hajóra emlékeztetett vitorlarudakkal és vitorlákkal, ahonnan az eljárás a nevét kapta. Például a $246 \times 387=95202$ szorzás a végén így nézet ki (bal oldalon a lenti ábrán):

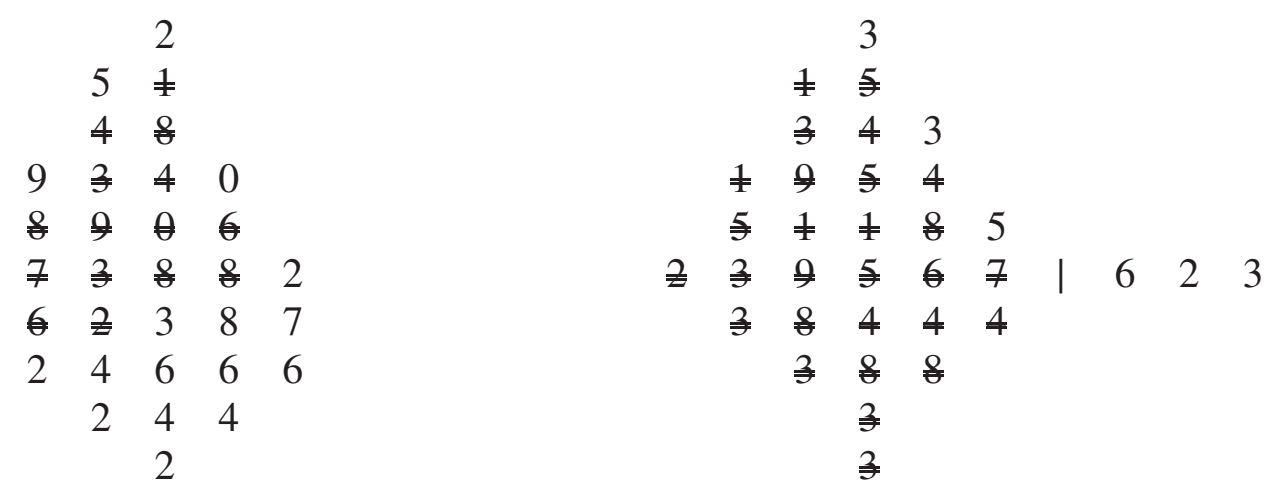




\subsection{Osztás}

A legelterjedtebb középkori módszer a több számjegyü számok osztására egy olyan eljárás volt, amely ugyanolyan nevet kapott, mint egy szorzás: galea vagy battello. Ez az algoritmus is Indiából származik, melyet poros táblákon végeztek el. A 239567: $384=623$ maradékkal 335 maradékos osztás az előző ábra jobb oldalán látható.

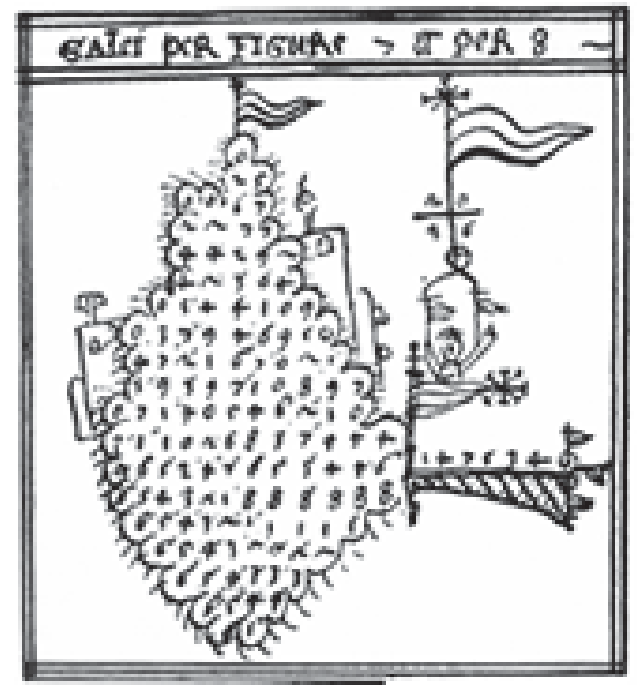

3. ábra. Egy 16. századi osztásnak a sziluettje

\section{6. Összefoglaló}

A középkor egy forduló korszakot jelentett a ma használt négy alapművelet elvégzésének kialakításában. A hatékonyság növekedésében alapvető tényező volt az Indiában kidolgozott tízes helyiértékes rendszer átvétele, továbbá az arab tudósok által alkalmazott számolási eljárások hozzáillesztése az európai körülményekhez. A dolgozatban néhány ilyen alapvető számolási módszert mutattunk, kitérve a szóban forgó korszak rövid történelmi hátterére.

\section{Köszönetnyilvánítás.}

A szerző szeretné kifejezni köszönetét a meghívásért Szalay László tanár úrnak, hogy részt tudott venni és hozzájárulni Sopronban a Matematika Oktatása és KUtatása Szeminárium (MOKUS) 2018-as munkájához. Szeretné még kifejezni mély köszönetet a Dimenziók szerkesztőségnek jelen szöveg a grammatikai korrekciójáért. Végül, de nem utolsó sorban, a szerzőt az RVO 67985807 stratégiai fejlesztési finanszírozás támogatta.

\section{Irodalomjegyzék}

[1] Le Goff, J., À la recherche du Moyen Âge (avec la collaboration de Jean-Maurice de Montremy), Louis Audibert, Paris, 2003.

[3] Városi, I., Szent Ágoston a keresztény tanitásról, Szent István Társulat, Budapest, 1944. 